\title{
Effect of Milling on the Carbothermal Reduction of Oxide Mixture for $(\mathrm{Ti}, \mathrm{W}) \mathrm{C}-\mathrm{Ni}$
}

\author{
Hanjung Kwon*1 and Shinhoo Kang*2 \\ Department of Materials Science and Engineering, Seoul National University, Seoul 151-742, Korea
}

The effect of high-energy milling on the phase transformation and carbothermal reduction was examined using an oxide mixture, $\mathrm{TiO}_{2}-\mathrm{WO}_{3}-\mathrm{NiO}-\mathrm{C}$, with a process to synthesize $(\mathrm{Ti}, \mathrm{W}) \mathrm{C}$ cermets. Due to the high energy involved in the mill raw, anatase $\mathrm{TiO}_{2}$ transformed first to $\mathrm{TiO}_{2}$-II and then to rutile, while $\mathrm{WO}_{3}$ transformed to a high-pressure $\mathrm{WO}_{3}-\mathrm{HP}$ and hexagonal $\mathrm{WO}_{3}$ phase. The co-existence of $\mathrm{WO} \mathrm{O}_{3}$ and $\mathrm{TiO}_{2}$ enhanced the formation of a nano-crystalline or amorphous phase. The (Ti,W)C phase was formed mainly at $1150^{\circ} \mathrm{C}$ from $\mathrm{TiC}$ and $\mathrm{WC}$ formed in the early stages. These results were further examined using XRD, the Rietveld method and mass spectroscopy. [doi:10.2320/matertrans.MRA2007267]

(Received November 1, 2007; Accepted April 21, 2008; Published June 25, 2008)

Keywords: solid-solution, cermets, high-energy milling, rietveld, mass spectrometer

\section{Introduction}

Titanium carbide and carbo-nitride are excellent materials in cutting tool applications, and are used in a wide range of cutting operations. ${ }^{1)} \mathrm{TiC}$ - and $\mathrm{Ti}(\mathrm{CN})$-based cermets are used in high-speed final or semi-final cutting tools in place of WC-Co alloys. ${ }^{2,3}$ However, the applications of such cermet systems are limited due to the low toughness of the cermets. The low toughness was ascribed to the complicated microstructure of $\mathrm{TiC}$ - or $\mathrm{Ti}(\mathrm{CN})$-based cermets and the poor wettability of the $\mathrm{Ni}$ binder phase on the carbides. WC addition to a $\mathrm{TiC}-\mathrm{Ni}$ or $\mathrm{Ti}(\mathrm{CN})-\mathrm{Ni}$ system is effective in improving the toughness and is decreasing the particle growth rate. ${ }^{4,5)}$

Cermets consisting of only $(\mathrm{Ti}, \mathrm{W}) \mathrm{C}$ - or $(\mathrm{Ti}, \mathrm{W})(\mathrm{CN})$-type solid-solution phase microstructures have been pursued since the 1980s. Recently, $(\mathrm{Ti}, \mathrm{W}) \mathrm{C}$ - or $(\mathrm{Ti}, \mathrm{W})(\mathrm{CN})$-type solidsolution phase microstructure was reported by Park et al. ${ }^{6}$ They reported that a solid-solution phase could be produced from an oxide mixture with greatly improved toughness compared with conventional TiC-based cermets. In addition, the temperature for the carbothermal reduction of the oxide mixture was reduced to $<1300^{\circ} \mathrm{C}$ through high-energy milling, which is remarkably lower than the conventional temperatures used $\left(1700 \sim 2000^{\circ} \mathrm{C}\right)$.

This study examined the effect of high-energy milling on the phase transformation of milled oxide mixture using the Rietveld method. This is in contrast to previous studies that reported a phase transformation with only one or two milled compounds such as $\mathrm{TiO}_{2}, \mathrm{~V}_{2} \mathrm{O}_{5}, \mathrm{ZrO}_{2}$, and metals ( $\mathrm{Ni}, \mathrm{Al}$, and $\mathrm{Ti}$ ) using this method. ${ }^{7-10)}$ The milling efficiency and phase transformation of the oxide mixture and individual oxides was also compared. The overall results were related to the carbothermal reduction and final phase formation process.

\footnotetext{
${ }^{* 1}$ Graduate Student, Seoul National University

${ }^{* 2}$ Corresponding author, E-mail: shinkang@ @snu.ac.kr
}

\section{Experimental Procedure}

The $(\mathrm{Ti}, \mathrm{W}) \mathrm{C}-\mathrm{Ni}$ powders were synthesized using anatase$\mathrm{TiO}_{2}$ (99+\% purity, $43 \mu \mathrm{m}$ ave. particle size, Aldrich), NiO (99\% purity, $45 \mu \mathrm{m}$ ave. particle size, Sigma-Aldrich) and $\mathrm{WO}_{3}(99+\%$ purity, $20 \mu \mathrm{m}$ avg. particle size, Aldrich). The oxides were mixed with carbon black to achieve the target composition, $\left(\mathrm{Ti}_{0.93} \mathrm{~W}_{0.07}\right) \mathrm{C}-20$ mass $\% \mathrm{Ni}, \quad \mathrm{TiC}-15$ mass $\%$, WC-20 mass $\% \mathrm{Ni}$. The carbon content was found not only to reduce all the oxides except for $\mathrm{NiO}$ to form $\mathrm{CO}$ but also to carburize the solid solution carbide, $(\mathrm{Ti}, \mathrm{W}) \mathrm{C}$.

The oxide/carbon mixture was subjected to high-energy ball milling using a planetary mill (Pulverisette 5, Fritsch, Germany). Tungsten carbide balls were mixed with the oxide/carbon mixture at a ball-to-powder ratio (BPR) of 40:1 by weight. Four WC-coated bowls were used, and each bowl contained 25 grams of the oxide mixture. All milling was carried out at a speed of $250 \mathrm{rpm}$ for periods of 5, 10 and $20 \mathrm{~h}$. The $(\mathrm{Ti}, \mathrm{W}) \mathrm{C}-\mathrm{Ni}$ powder was prepared by carbothermal reduction at $1200^{\circ}$ or $1300^{\circ} \mathrm{C}$ for $1 \mathrm{~h}$.

The specimens were analyzed by X-ray diffraction (M18XHF-SRA, Macscience, Japan) with Si as the standard. The crystallite size and phase transformation after milling the oxide mixture were investigated using the Rietveld and integral breadth methods after eliminating the instrumental broadening factor. The amount of gas evolution during carbothermal reduction was measured using a mass spectrometer (QMS 403, NETZSCH, Germany) under helium flow.

\section{Results and Discussion}

\subsection{Milling effect on phase transformation}

Figure 1 shows the sequential XRD profiles of $\mathrm{TiO}_{2}-\mathrm{WO}_{3}-$ $\mathrm{NiO}-\mathrm{C}$ mixtures with respect to the high-energy milling time. In general, the intensities of the profiles were relatively low, even after $5 \mathrm{~h}$ milling (Fig. 1(a)), while many peaks combined with time (Fig. 1(c)). Figure 1(d) shows the final phases, $(\mathrm{Ti}, \mathrm{W}) \mathrm{C}$ and $\mathrm{Ni}$, obtained from the carbothermal reduction of the powder shown in Fig. 1 (c) at $1300^{\circ} \mathrm{C}$ for $1 \mathrm{~h}$. 


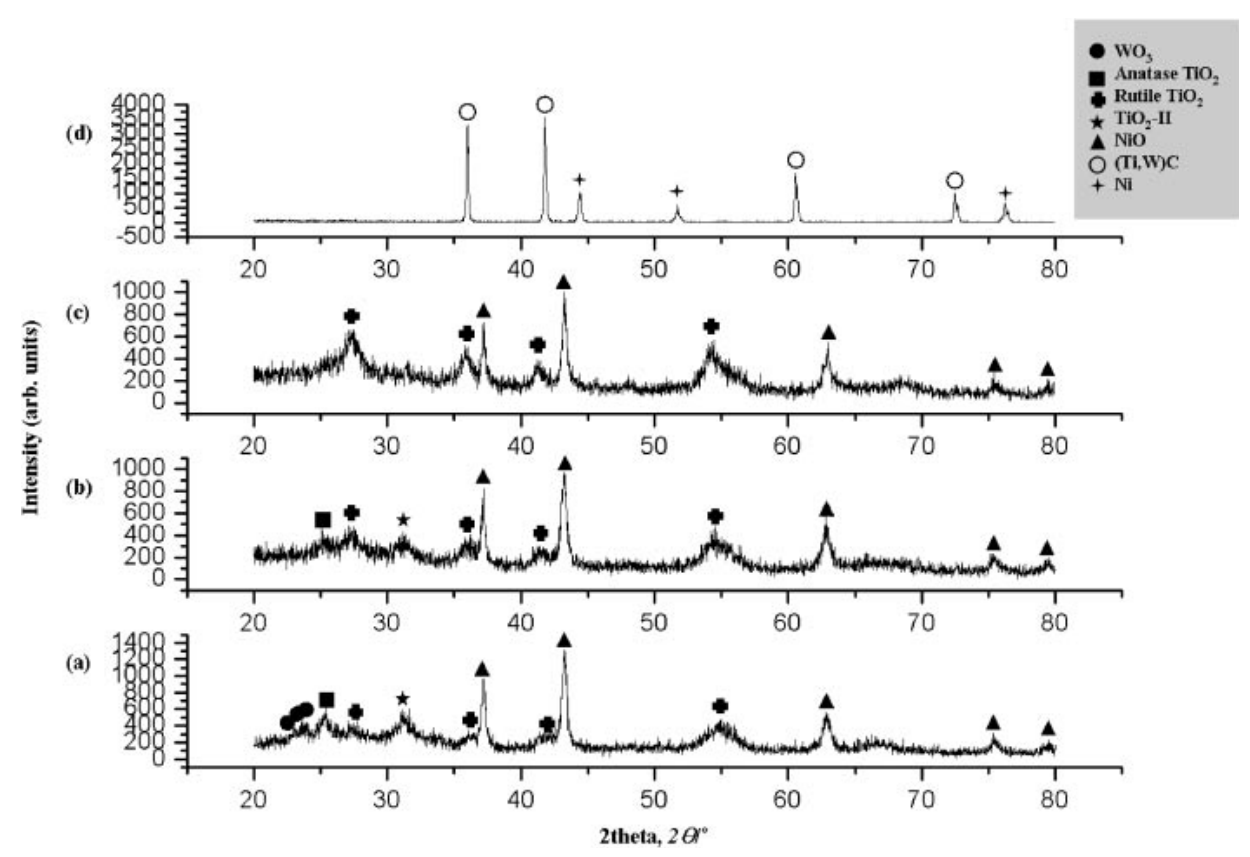

Fig. 1 XRD profiles of $\mathrm{TiO}_{2}-\mathrm{WO}_{3}-\mathrm{NiO}-\mathrm{C}$ mixtures after planetary milling for (a) $5 \mathrm{~h}$, (b) $10 \mathrm{~h}$, (c) $20 \mathrm{~h}$, and (d) after carbothermal reduction of (c) at $1300^{\circ} \mathrm{C}$ for $1 \mathrm{~h}$.

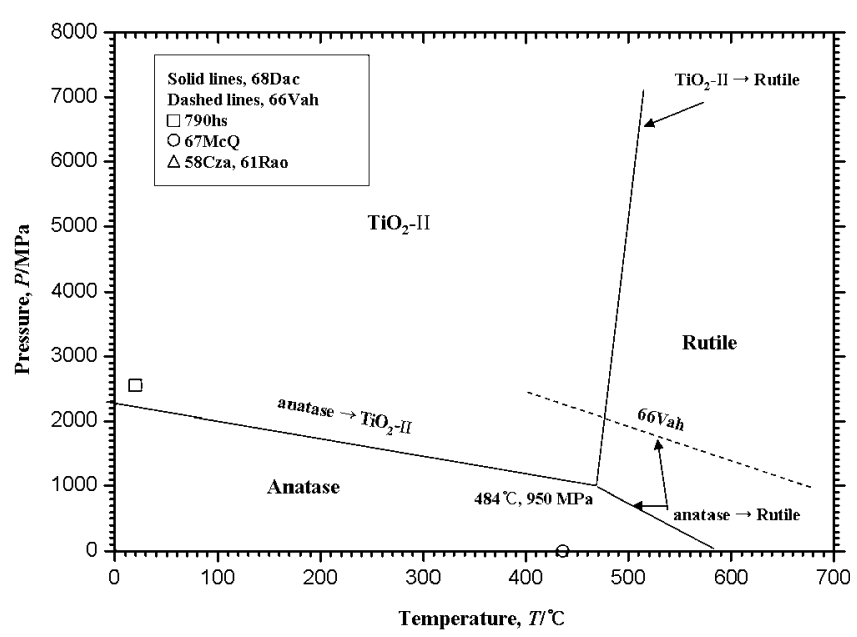

Fig. 2 Phase Diagram of $\mathrm{TiO}_{2}$ as a function of temperature and pressure. ${ }^{14)}$

In the initial stage of milling, new phases appear, such as rutile $\mathrm{TiO}_{2}$ and a high-pressure $\mathrm{TiO}_{2}$-II phase (Fig. 1(a) and (b)). In addition, $\mathrm{TiO}_{2}$-II forms preferentially over rutile. In the late stage, rutile grows dominantly by consuming $\mathrm{TiO}_{2}$-II (Fig. 1(b) and (c)). Apparently, raw anatase $\mathrm{TiO}_{2}$ transformed to two new phases that are stable at high temperature and/or high pressure. The sequence of phase transformation, anatase to $\mathrm{TiO}_{2}$-II to rutile, has already been reported in the literature for the milling of anatase $\mathrm{TiO}_{2}$. The impact induced from the milling actions is regarded as the main reason for high pressure $\mathrm{TiO}_{2}$-II synthesized during milling. ${ }^{11-13)}$

This result is consistent with the phase diagram shown in Fig. 2 where the anatase and $\mathrm{TiO}_{2}$-II phases change into rutile under high pressures and temperatures. ${ }^{14)}$ Based on Figs. 1 and 2, it can be said that raw anatase $\mathrm{TiO}_{2}$ transforms to $\mathrm{TiO}_{2}$-II first and then to rutile when the temperature of the vessels and impact are high enough in the planetary mill.
This result implies that high pressures $(>2500 \mathrm{MPa})$ and temperatures $\left(>500^{\circ} \mathrm{C}\right)$ prevail during milling, which allows such transformations.

The milling efficiency of the planetary mill was compared with that of the attrition mill, which is commonly used for powder preparation. Attrition milling was performed with the same quantity of oxide mixture (100 gram) in a vessel under the same milling conditions as the planetary mill: speed of $250 \mathrm{rpm}$ with a BPR of 40:1. Figure 3 shows the XRD results of the powder after attrition milling. A high level of crystallinity of various phases was observed without complete alloying, even after $20 \mathrm{~h}$ attrition milling.

In the attrition mill, rutile appears first after $5 \mathrm{~h}$ milling, which is followed by $\mathrm{TiO}_{2}$-II after $10 \mathrm{~h}$ milling. The attrition mill in this study does not provide sufficient impact to form $\mathrm{TiO}_{2}$-II. Instead, the $\mathrm{TiO}_{2}$-II phase forms at a relatively low pressure due to an increase in vessel temperature (Fig. 2). Both phases are retained in the powder attrition-milled for $20 \mathrm{~h}$. However, the intensity of these phases is not significant compared with those of the other phases in the system.

Rietveld analysis was also performed to examine the phase transformations in more detail in that it is a reliable technique for the estimation of the grain size of these phases. The Rietveld analysis for the overlapped peaks is shown in Fig. 4. Table 1 shows the phases present in the powder milled by the attrition and planetary mills for $20 \mathrm{~h}$. It also lists their space group, crystal structure and final grain size of the phases found from the planetary mill. This analysis reconfirms that there are three different types of $\mathrm{TiO}_{2}$ in the system. The possible presence of srilankite $\mathrm{TiO}_{2}$ was also noted in the powder milled using the planetary mill. $\mathrm{WO}_{3}$ transforms to a high-pressure $\mathrm{WO}_{3}-\mathrm{HP}$ and hexagonal $\mathrm{WO}_{3}$ in the planetary mill, whereas $\mathrm{W}(\mathrm{CO})_{6}$ was found in the attrition mill. The transformation can vary significantly according to the milling techniques or impact. 


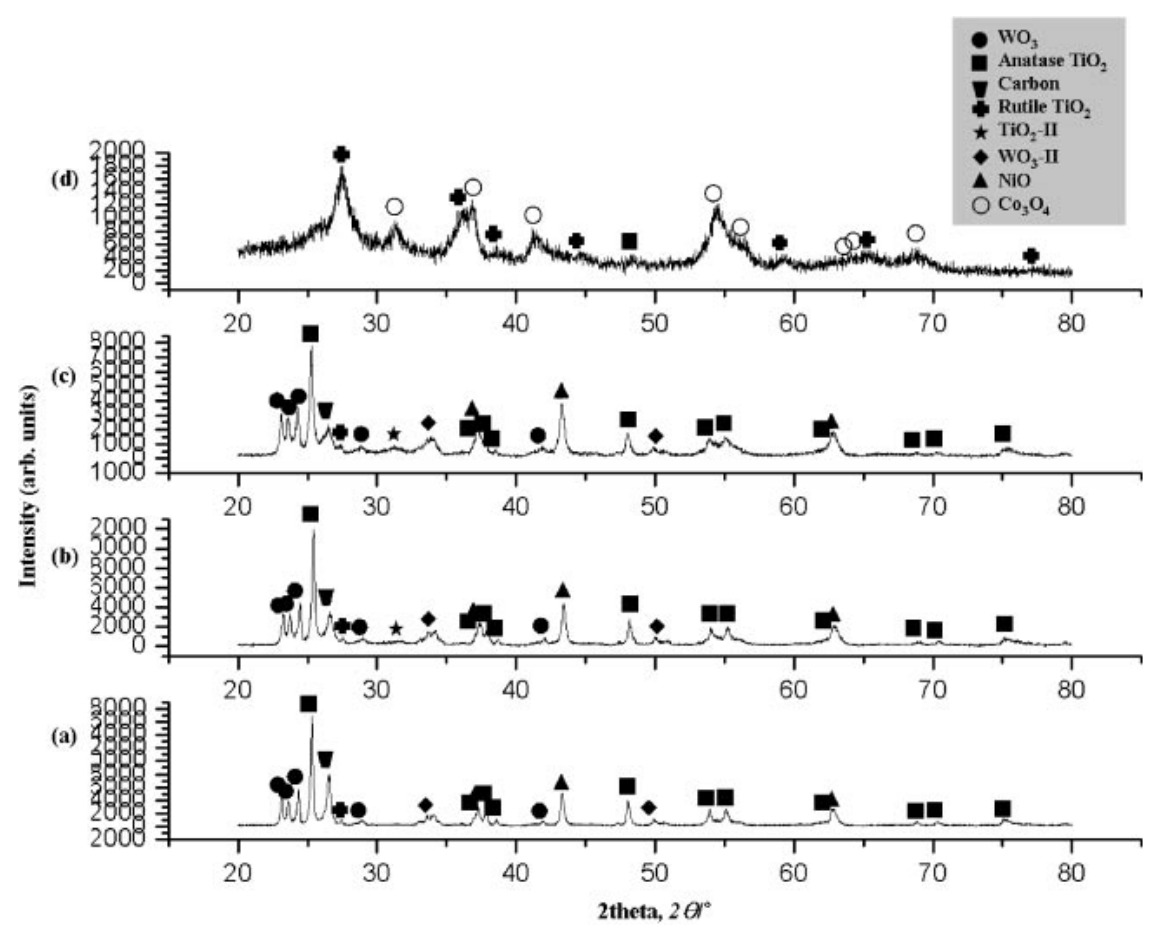

Fig. 3 XRD profile of $\mathrm{TiO}_{2}-\mathrm{WO}_{3}-\mathrm{NiO}-\mathrm{C}$ mixtures after attrition milling for (a) $5 \mathrm{~h}$, (b) $10 \mathrm{~h}$, (c) $20 \mathrm{~h}$ and (d) $20 \mathrm{~h}$ with $\mathrm{Co}_{3} \mathrm{O}_{4}$ in place of $\mathrm{NiO}$ (planetary milling).

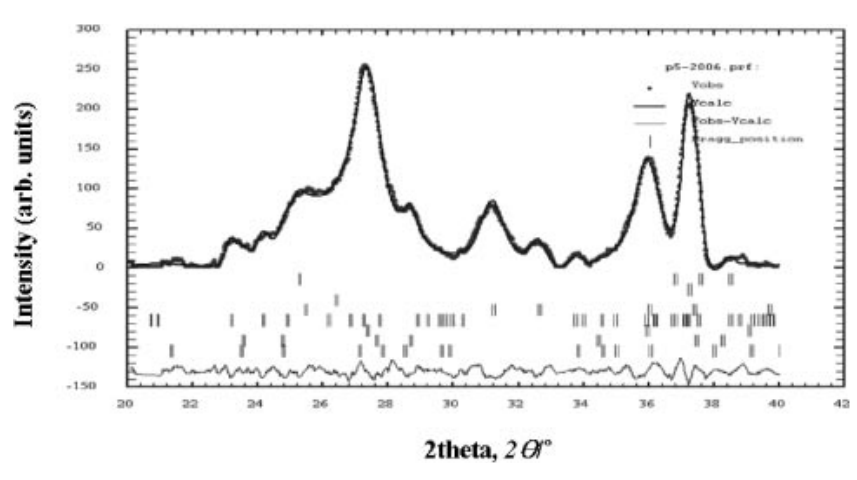

Fig. 4 Rietveld analysis about the overlapped $\mathrm{XRD}$ profiles of $\mathrm{TiO}_{2}-\mathrm{WO}_{3}$ $\mathrm{NiO}-\mathrm{C}$ mixtures after planetary milling for $20 \mathrm{~h}$.
Figures 1 and 3 show the broadening of the peaks for the various phases in the system. They suggest that all phases are nano-crystalline after $5 \mathrm{~h}$ milling. The results of the Scherrer's method revealed the size of crystallites milled using the attrition technique exceeds the limit of the method $(>100 \mathrm{~nm})$. However, the average size of rutile in the planetary mill $<10 \mathrm{~nm}$ while that of raw anatase was $43 \mu \mathrm{m}$ initially and was milled to $\sim 30 \mathrm{~nm}$ (Table 1 ).

\subsection{Compositional effect on milling efficiency}

It is interesting to find that $\mathrm{NiO}$ remained unmixed, which is in contrast to the other oxides, as shown in Figs. 1 and 3. This might be due to its crystal structure and mechanical properties. The melting points of $\mathrm{TiO}_{2}, \mathrm{WO}_{3}$ and $\mathrm{NiO}$ are 1800,1473 and $1960^{\circ} \mathrm{C}$, respectively. The highest melting point of $\mathrm{NiO}$ among the oxides is often related to its strong bond strength, which causes high hardness. However, the

Table 1 Microstructural parameters of the powder after attrition and planetary milling for $20 \mathrm{~h}$.

\begin{tabular}{|c|c|c|c|c|c|c|}
\hline \multicolumn{2}{|c|}{ Starting materials } & \multirow{2}{*}{$\begin{array}{c}\begin{array}{c}\text { Powder after attrition } \\
\text { milling }\end{array} \\
\text { Phase }\end{array}$} & \multicolumn{4}{|c|}{ Powder after planetary milling } \\
\hline Phase & $\begin{array}{c}\text { Crystallite size, } \\
\mu \mathrm{m}\end{array}$ & & Phase & $\begin{array}{c}\text { Crystallite size, } \\
\mathrm{nm}\end{array}$ & Crystal system & Space group \\
\hline \multirow{3}{*}{$\mathrm{TiO}_{2}$-Anatase } & \multirow{3}{*}{43} & $\mathrm{TiO}_{2}$-Anatase & $\mathrm{TiO}_{2}$-Anatase & 21.7 & Tetragonal & I41/amd \\
\hline & & $\mathrm{TiO}_{2}-\mathrm{II}$ & $\mathrm{TiO}_{2}-\mathrm{II}$ & 31.2 & Orthorhombic & Pbcn \\
\hline & & $\mathrm{TiO}_{2}$-Rutile & $\mathrm{TiO}_{2}$-Rutile & 7.6 & Tetragonal & $\mathrm{P} 42 / \mathrm{mnm}$ \\
\hline \multirow{3}{*}{$\mathrm{WO}_{3}$-mono } & \multirow{3}{*}{20} & \multirow{2}{*}{$\mathrm{WO}_{3}$-mono } & $\mathrm{WO}_{3}$-mono & $*$ & Monoclinic & $\mathrm{P} 21 / \mathrm{n}$ \\
\hline & & & $\mathrm{WO}_{3}-\mathrm{HP}$ & $*$ & Monoclinic & $\mathrm{P} 21 / \mathrm{c}$ \\
\hline & & $\mathrm{W}(\mathrm{CO})_{6}-\mathrm{Pnma}$ & $\mathrm{WO}_{3}$-hex & $*$ & Hexagonal & $\mathrm{P} 6 / \mathrm{mmm}$ \\
\hline $\mathrm{NiO}$ & 45 & $\mathrm{NiO}$ & $\mathrm{NiO}$ & 52.7 & Cubic & $\mathrm{Fm} 3 \mathrm{~m}$ \\
\hline $\mathrm{C}$ & 1.65 & $\mathrm{C}$ & $\mathrm{C}$ & 3.3 & Hexagonal & $\mathrm{P} 63 \mathrm{mc}$ \\
\hline
\end{tabular}

${ }^{*}$ Fraction of the phase was less than 5 mass $\%$ and therefore the grain value is not reliable, BPR=ball-to-powder weight ratio. 
hardness values of $\mathrm{NiO}$ and $\mathrm{TiO}_{2}$ are found to be about the same as 5.5 and $5.5 \sim 6 \mathrm{GPa}$, respectively. It seems to rule out the influence of mechanical properties of $\mathrm{NiO}$ as a possible cause for unaccountable milling behavior of $\mathrm{NiO}$.

The crystal structure aspect of $\mathrm{NiO}$ was examined as another possible reason for the immiscibility issue. $\mathrm{NiO}$ has a cubic structure that belongs to the space group, Fm3m, which is different from that of the other phases, Pabc. A different oxide, $\mathrm{Co}_{3} \mathrm{O}_{4}$ with a cubic structure that belongs to space group, $\mathrm{Fd} 3 \mathrm{~m}$, was used in place of $\mathrm{NiO}$ for comparison. As shown in Fig. 3(d) peak broadening was noted with much lower peak intensity. The mixing tendency was superior to $\mathrm{NiO}$, resulting in a homogeneous nano-crystalline or amorphous phase. The melting point of $\mathrm{Co}_{3} \mathrm{O}_{4}$ is $900^{\circ} \mathrm{C}$, indicating that it has lower bond strength than $\mathrm{NiO}$. Based on the information above, it is likely that the milling behavior of $\mathrm{NiO}$ is largely attributed to the relatively high mechanical strength of $\mathrm{NiO}$ more than the difference in crystal structure among constituent oxides in the system.

No phase transformation was observed from NiO. This is only because $\mathrm{NiO}$ has the lowest amount of oxygen among the Ni-O compounds. There are four different types of nickel oxides, $\mathrm{NiO}, \mathrm{NiO}_{2}$ of $\mathrm{C} 2 / \mathrm{m}$ and $\mathrm{R}-3 \mathrm{~m}$, and $\mathrm{Ni}_{2} \mathrm{O}_{3} .{ }^{15-17)}$ All nickel oxides will change to $\mathrm{NiO}$ first in a reducing atmosphere. The melting points of $\mathrm{NiO}_{2}$ of $\mathrm{C} 2 / \mathrm{m}$ and $\mathrm{R}-3 \mathrm{~m}$, and $\mathrm{Ni}_{2} \mathrm{O}_{3}$ are presumed to be the same as that of $\mathrm{NiO}$ since they are dissociated into $\mathrm{NiO}$. The dissociation of unstable $\mathrm{Ni}_{2} \mathrm{O}_{3}$ is known to occur $\sim 600^{\circ} \mathrm{C}$. ${ }^{18)}$ These facts support our assertion above.

The use of rutile $\mathrm{TiO}_{2}$ as a raw oxide, instead of anatase, was examined to determine the effect of the transformation on the reduction process. The result, after $20 \mathrm{~h}$ milling, is shown in Fig. 5. In the case of rutile, the milling impact was less than that of anatase. Using the (012) peak of $\mathrm{NiO}$ as a reference, the intensity ratios of the $\mathrm{TiO}_{2}(120)$ peak to $\mathrm{NiO}$ (012) peak were 0.73 and 1.02 in the cases of anatase and rutile, respectively (Fig. 5). The milling behavior of $\mathrm{NiO}$ is assumed to be more or less inert to the kind of $\mathrm{TiO}_{2}$. The use of anatase lowers effectively the crystallinity of the
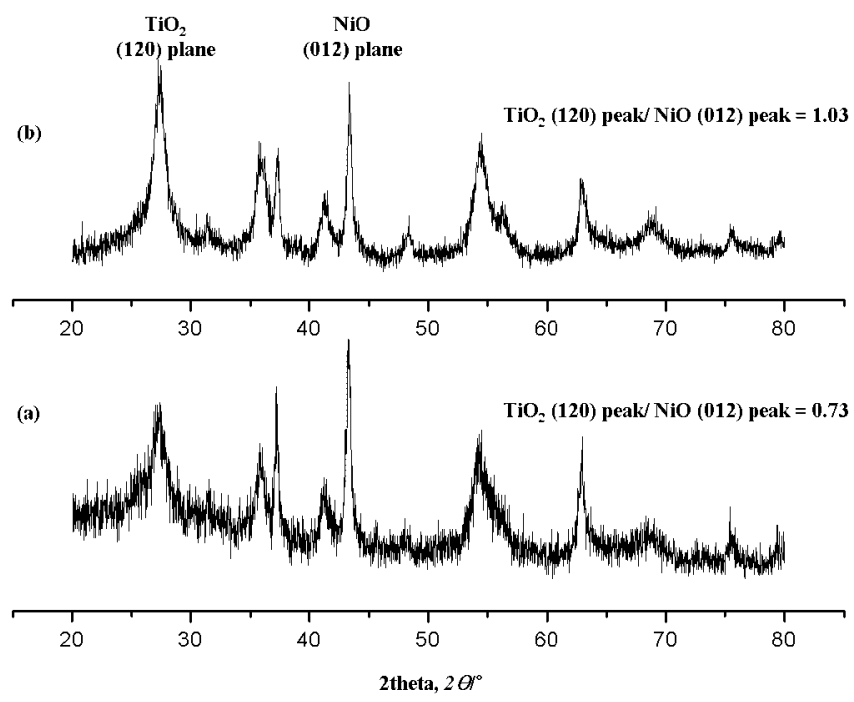

Fig. 5 XRD patterns of the oxide mixture milled for $20 \mathrm{~h}$ using (a) anatase $\mathrm{TiO}_{2}$ and (b) rutile $\mathrm{TiO}_{2}$. rutile $\mathrm{TiO}_{2}$ phase formed after milling. This demonstrates that the two different starting $\mathrm{TiO}_{2}$ oxides take different paths to arrive at nano-crystalline rutile. The anatase phase initially becomes disordered to some extent in structure by mechanical impact and then begins forming nano-crystalline rutile via $\mathrm{TiO}_{2}$-II.

Mass spectroscopy also demonstrates that when anatase is used, the reduction begins at a $\sim 100^{\circ} \mathrm{C}$ lower temperature than with rutile. There was no further transformation of $\mathrm{TiO}_{2}$ observed when rutile was used even if the size of rutile was smaller than that of anatase. Based on these results, the use of anatase is an important factor for lowering the crystallinity of the system and inducing a proper phase transformation.

The effect of other oxides in inducing relevant transformations was investigated by examining the milling behavior of the individual oxides with carbon. The same amount of the individual oxide was milled with the same amount of carbon as that of the oxide mixture. That is, for the milling of the individual oxide mixture, such as $\mathrm{TiO}_{2}, \mathrm{WO}_{3}$ and $\mathrm{NiO}$ along with $\mathrm{C}$, the same volume ratio of milling ball to powder was used instead of the weight ratio to mix the $\mathrm{TiO}_{2}-\mathrm{WO}_{3}-\mathrm{NiO}-\mathrm{C}$ powder. The volume ratios were recalculated to weight ratios later.

When a mixture of $\mathrm{TiO}_{2} / \mathrm{C}$ was milled for $20 \mathrm{~h}$, anatase phase transformed completely to rutile, as shown in Fig. 6(a). However, the crystallinity was much higher than that of the oxide mixture. Figure 6(b) and (c) show that partial reduction occurred when $\mathrm{WO}_{3}$ or $\mathrm{NiO}$ was milled with $\mathrm{C}$, resulting in $\mathrm{WO}_{2}$ and hexagonal $\mathrm{Ni}$. Compared with the result shown in Fig. 1, $\mathrm{WO}_{3}$ can be alloyed effectively in the form of nanocrystalline or amorphous phases in the presence of other oxides such as $\mathrm{TiO}_{2}$. This confirms that the $\mathrm{NiO} / \mathrm{C}$ mixture has the least milling and miscibility among oxides. The presence of WC in this system was due to contamination from the milling media.

\subsection{Carbothermal reduction of milled oxide mixture}

Figure 7 shows the evolution of $\mathrm{CO} / \mathrm{CO}_{2}$ gas measured using a mass-spectrometer from the oxide mixtures milled for 5,10 , and $20 \mathrm{~h}$. The temperature range for the reduction was varied with respect to the milling time. While the onset temperature of the $\mathrm{CO} / \mathrm{CO}_{2}$ gas evolution is $\sim 530^{\circ} \mathrm{C}$ for the powder milled for $5 \mathrm{~h}, \mathrm{CO} / \mathrm{CO}_{2}$ gas is released at $\sim 500$ and $450^{\circ} \mathrm{C}$ in case of 10 and $20 \mathrm{~h}$ milling, respectively. A thermodynamic calculation shows that $\mathrm{CO}_{2}$ is more stable at a lower temperature than $\mathrm{CO}$. According to the Ellingham diagram, ${ }^{19)}$ the coexistence of $\mathrm{CO}$ and $\mathrm{CO}_{2}$ gases prevails up to $\sim 1130^{\circ} \mathrm{C}$ with unmilled oxides if the total pressure is maintained at $1 \times 10^{5} \mathrm{~Pa}$. In this case, the temperature decreases to $\sim 500^{\circ} \mathrm{C}$, even if the reduction environment is much different from the standard state. With the milled powder of this study, the $\mathrm{CO}$ evolution was completed at a lower temperature, $1200^{\circ} \mathrm{C}$, with increasing milling time (Fig. 7(c)). Therefore, the level of crystallinity and extent of phase transformation during milling determine the temperature needed to complete the reduction.

Figure 8 shows the changes in weight and the thermal behavior of the milled oxide mixture obtained by TG-DSC. The first discrete drop in TG (see the arrow) was attributed 


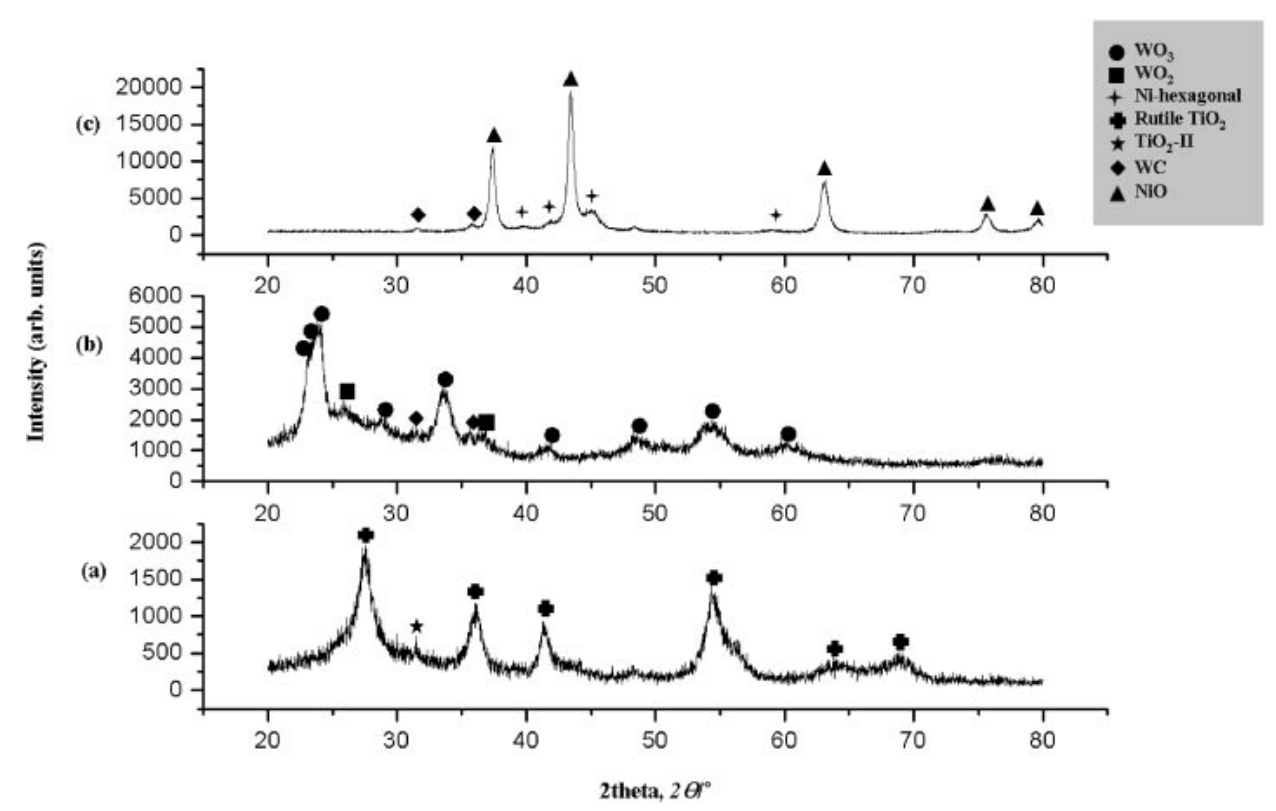

Fig. 6 XRD patterns of (a) anatase $\mathrm{TiO}_{2}+\mathrm{C}$, (b) $\mathrm{WO}_{3}+\mathrm{C}$ and (c) $\mathrm{NiO}+\mathrm{C}$ after $20 \mathrm{~h}$ planetary milling.

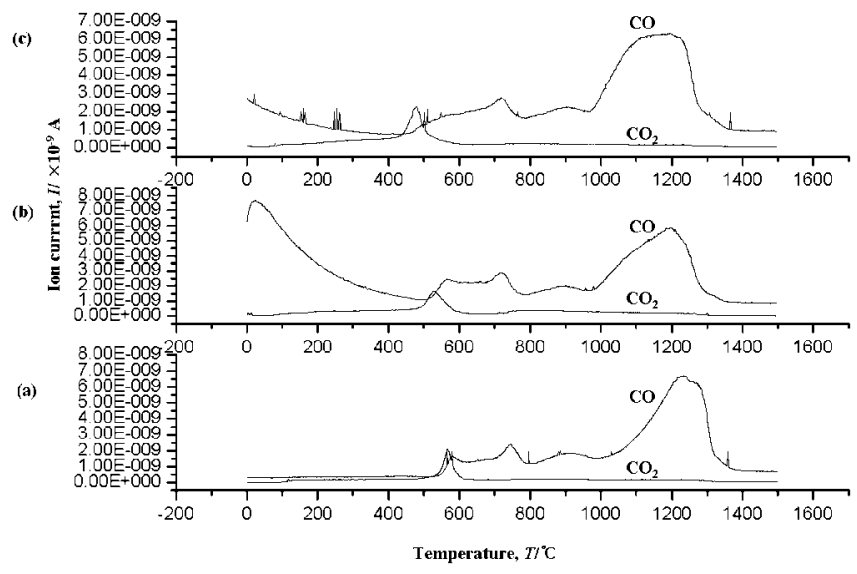

Fig. 7 Gas evolution of $\mathrm{CO} / \mathrm{CO}_{2}$ during carbothermal reduction of $\mathrm{TiO}_{2}+\mathrm{WO}_{3}+\mathrm{NiO}+\mathrm{C}$ mixture after high-energy milling for (a) $5 \mathrm{~h}$, (b) $10 \mathrm{~h}$, and (c) $20 \mathrm{~h}$.

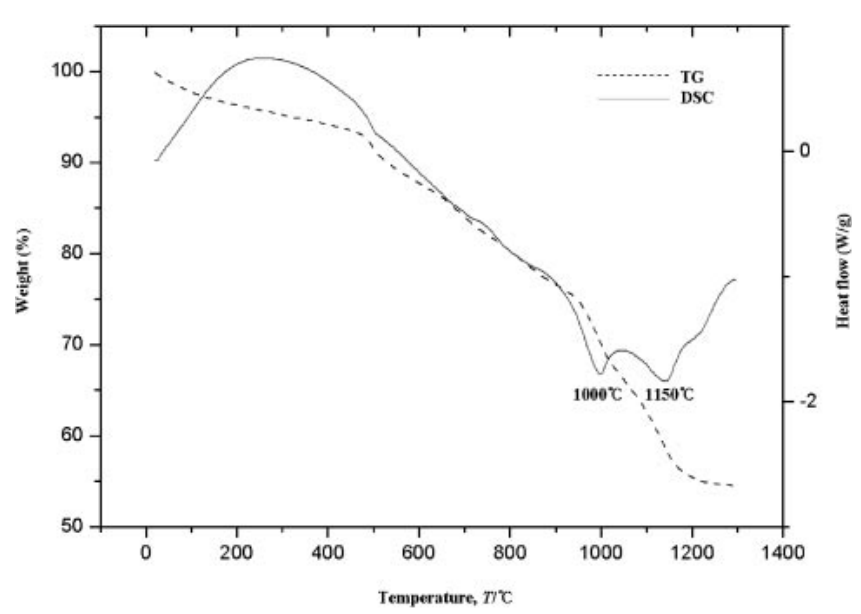

Fig. 8 Mass change and heat flow during carbothermal reduction measured by TG-DSC.
Table 2 The phases observed after carbothermal reduction at various temperatures for $1 \mathrm{~h}$.

\begin{tabular}{cccccc}
\hline & $500^{\circ} \mathrm{C}$ & $800^{\circ} \mathrm{C}$ & $1000^{\circ} \mathrm{C}$ & $1100^{\circ} \mathrm{C}$ & $1150^{\circ} \mathrm{C}$ \\
\hline & & $\mathrm{TiO}_{2}-\mathrm{Rutile}$ & $\mathrm{TiC}$ & $\mathrm{TiC}$ & \\
Phases & $\mathrm{TiO}_{2}$-Rutile & $\mathrm{Ti}_{4} \mathrm{O}_{7}$ & $\mathrm{Ti}_{4} \mathrm{O}_{7}$ & $\mathrm{Ti}_{3} \mathrm{O}_{5}$ & $(\mathrm{Ti}, \mathrm{W}) \mathrm{C}$ \\
confirmed from & $\mathrm{WC}$ & $\mathrm{Ti}_{3} \mathrm{O}_{5}$ & $\mathrm{Ti}_{3} \mathrm{O}_{5}$ & $\mathrm{Ti}_{2} \mathrm{O}_{3}$ & $\mathrm{WC}$ \\
XRD analysis & $\mathrm{Ni}$ & $\mathrm{WC}$ & $\mathrm{WC}$ & $\mathrm{WC}$ & $\mathrm{Ni}$ \\
& & $\mathrm{Ni}$ & $\mathrm{Ni}$ & $\mathrm{Ni}$ & \\
\hline
\end{tabular}

to the reduction of $\mathrm{NiO}$, which was confirmed by mass spectrometry for the $\mathrm{NiO} / \mathrm{C}$ mixture. Since then, there was a continuous decrease in the oxide mixture until it reached $1200^{\circ} \mathrm{C}$. This is in line with the result shown in Fig. 7. In order to have accurate analyses for the reactions, the oxide mixture, which had been milled for $20 \mathrm{~h}$, was heat treated at various temperatures for $1 \mathrm{~h}$. Table 2 summarizes the XRD results of the mixture. The results show that the rutile phase was continuously reduced into a suboxide, $\mathrm{TiO}_{2-\mathrm{x}}$, until it reached $1000^{\circ} \mathrm{C}$. Various suboxides appeared and were reduced at a faster rate than rutile. This can indicate the relative stability of the oxides examined in this study.

In addition, differential scanning calorimetry (DSC) shows two distinct endothermic reactions that are completed in the vicinity of $1000^{\circ} \mathrm{C}$ and $1150^{\circ} \mathrm{C}$, respectively in Fig. 8 . According to Table 2, TiC begins forming in the vicinity of $1000^{\circ} \mathrm{C}$ while the formation of $\mathrm{WC}$ is almost complete at $\sim 800^{\circ} \mathrm{C}$. Since the thermal gravitometry (TG) results indicates no more weight loss from $1150^{\circ} \mathrm{C}$, it is believed that $(\mathrm{Ti}, \mathrm{W}) \mathrm{C}$ formation occurs at this temperature from $\mathrm{TiC}$ and $\mathrm{WC}$, which had already formed below $1150^{\circ} \mathrm{C}$. $^{20)}$

\section{Summary and Conclusions}

This study examined the effect of high-energy milling on the phase transformation of a milled oxide mixture, $\mathrm{TiO}_{2}$ - 
$\mathrm{WO}_{3}$-NiO-C. The effect of the mixture on the milling efficiency was related to the carbothermal reduction and final phase formation process. In high-energy milling, raw anatase $\mathrm{TiO}_{2}$ transforms first to $\mathrm{TiO}_{2}$-II and then to rutile in the form of a nanocrystalline phase, while $\mathrm{WO}_{3}$ transforms to a high-pressure $\mathrm{WO}_{3}-\mathrm{HP}$ and hexagonal $\mathrm{WO}_{3}$. The presence of the $\mathrm{WO}_{3}$ phase helps form a nano-crystalline or amorphous phase with $\mathrm{TiO}_{2}$ due to its low bond strength and brittle nature. $\mathrm{TiC}$ begins to form in the vicinity of $1000^{\circ} \mathrm{C}$ while the formation of $\mathrm{WC}$ is almost complete at $\sim 800^{\circ} \mathrm{C}$. $(\mathrm{Ti}, \mathrm{W}) \mathrm{C}$ formation occurs mainly at $1150^{\circ} \mathrm{C}$ from $\mathrm{TiC}$ and WC, which have formed previously.

\section{Acknowledgements}

This work was supported partially by the MOCIE (Ministry of Commerce, Industry and Energy) research fund under contract \#10023338 and partially by a grant-in-aid for the National Core Research Center Program from MOST and KOSEF (No. R15-2006-022-R15-2006-022-03001-0). Our special thanks go to Dr. J. Joardar for the help in preparing the manuscript.

\section{REFERENCES}

1) L. E. Toth: Transition Metal Carbides and Nitrides, Edited by John L. Margrave, (ACADEMIC PRESS, New York and London, 1971) p. 1.

2) R. Kieffer, P. Ettmayer and M. Freundhofeier: Powder Metall. 25
(1971) 1335.

3) R. Kieffer, P. Ettmayer and M. Freundhofeier: Modern devices in powder metals, (Plenum Press, New York, 1971) pp. 201-14.

4) H. Suzuki, K. Hayashi, H. Matsubara and K. Tokumoto: Jpn. Soc. Powder Powder Metall. 30 (1983) 106-11.

5) M. Ueki: Jpn. Soc. Powder Powder Metall. 40 (1993) 743-59.

6) S. Park and S. Kang: Scr. Mater. 52 (2005) 129-133.

7) S. K. Manik, H. Dutta and S. K. Pradhan: Mater. Chem. Phys. 82 (2003) 848-859.

8) H. Data and S. K. Parhamm: Mater. Chem. Phys. 77 (2002) 868-877.

9) P. Shaun, M. De and M. Zdujic: Mater. Chem. Phys. 82 (2003) 864-876.

10) H. Data, S. K. Parham and M. De: Mater. Chem. Phys. 74 (2002) 167-176.

11) S. Begin-Colin, T. Girot, G. Le Caer and A. Mocellin: J. Solid State Chem. 149 (2000) 41-48.

12) A. Gajovic, K. Furic, N. Tomasic, S. Popovic, Z. Skoko and S. Music: J. Alloys Compd. 398 (2005) 188-199.

13) S. Coste, G. Bertrand, C. Coddet, E. Gaffet, H. Hahn and H. Sieger: J. Alloys Compd. 434-435 (2007) 489-492.

14) J. L. Murray and H. A. Wriedt Bull.: Alloy Phase Diag. 7 (1987) $148-165$.

15) K. Martin and G. McCarthy: North Dakota State Univ., Fargo, ND, USA, ICDD Grant-in-Aid (1991).

16) Calculated from ICSD using POWD-12++ 147 (1990) 410.

17) A. Goswami: J. Phys. Chem. 65 (1961) 2105.

18) F. A. Cotton, G. Wilkinson, C. A. Murillo and M. Bochmann: Advanced Inorganic Chemistry, (John Wiley \& Sons, New York, 1999).

19) D. R. Gaskell: Introduction to the Thermodynamics of Materials, ( $4^{\text {th }}$ ed., Tylor \& Francis, New York and London, 2003) p. 359.

20) S. Park, Y. J. Kang, H. J. Kwon and S. Kang: Int. J. Ref. Met. \& H. Mat. 24 (2006) 115-121. 